\begin{tabular}{|l|l|l|l|}
\hline $\begin{array}{l}\text { Eiszeitalter und Gegenwart } \\
\text { Quaternary Science Journal }\end{array}$ & $\mathbf{5 8 / 1}$ & $55-69$ & Hannover 2009 \\
\hline
\end{tabular}

\title{
Pupilla loessica LožEK 1954 (Gastropoda: Pulmonata: Pupillidae) - "A Living Fossil" in Central Asia?
}

\author{
Stefan Meng \& Matthias H. Hoffmann *)
}

\begin{abstract}
LožEK (1986) is of the opinion that Pupilla loessica has been found recently in Central Asia. The aim of this study is to provide some initial, concrete contributions to the discussion of this subject. It should be understood as a basis for further investigations. During recent visits on site between 1995 and 2006 in Central Asia in the Russian Altay, in Northern Mongolia, in the Baikal region and in the Tien Shan, numerous recent malacocenoses were examined. In many places evidence was found of a form of Pupilla which had not previously been described from this region; its shell morphology cannot be distinguished from Pupilla loessica. Its distribution is concentrated in the strongly continental Khrebet Saylyugem in the South Eastern Altay. The probability of the occurrence of Pupilla loessica in Central Asia is supported, apart from the shell morphology criteria, by the preference of this species for more continental types of habitat with average annual temperatures markedly below $0^{\circ} \mathrm{C}$ and the corresponding accompanying fauna adapted to the cold, including e.g. Columella columella, Vertigo genesii, Vallonia tenuilabris, etc., which make these fauna easily comparable to the Pleistocene glacial associations of the Central European region.
\end{abstract}

[Pupilla loessica LožEK 1954 (Gastropoda: Pulmonata: Pupillidae) -“Ein lebendes Fossil” in Zentralasien?]

Kurzfassung: LožEK (1986) vertritt die Ansicht, dass Pupilla loessica rezent in Zentralasien vorkommt. Die vorliegende Studie hat das Ziel zu diesem Thema erste konkrete Diskussionsbeiträge zu liefern. Zu verstehen ist diese Arbeit als Grundlage für weitergehende Untersuchungen. Bei neueren Geländeaufenthalten von 1995-2006 konnten in Zentralasien im Russischen Altay, in der nördlichen Mongolei, im Baikal-Gebiet und im Tien Shan zahlreiche rezente Malakozönosen untersucht werden. An vielen Lokalitäten wurde eine bisher aus dieser Region unbeschriebene Form von Pupilla nachgewiesen, welche gehäuse-morphologisch von Pupilla loessica nicht zu unterscheiden ist. Einen Schwerpunkt der Verbreitung bildet das stark kontinental geprägte Khrebet Saylyugem im SE-Altay. Für das Vorkommen von Pupilla loessica in Zentralasien spricht neben den gehäuse-morphologischen Kriterien, die Präferenz dieser Form zu stärker kontinental geprägten Habitaten, mit Jahresdurchschnittstemperaturen, die deutlich unter $0^{\circ} \mathrm{C}$ liegen sowie die entsprechenden kälteangepassten Begleitfaunen, z. B. mit Columella columella, Vertigo genesii, Vallonia tenuilabris u. a., welche diese Faunen gut mit den pleistozänen kaltzeitlichen Assoziationen des mitteleuropäischen Raumes vergleichbar machen.

Keywords: Pupilla loessica, living fossil, Central Europe, Central Asia

* Adresses of authors: S. Meng, Ernst Moritz Arndt University Greifswald, Institute of Geography and Geology, Friedrich-Ludwig-Jahnstrasse 17a, 17487 Greifswald, Germany. stefan.meng@uni-greifswald.de; H. Hoffmann, Martin Luther University Halle-Wittenberg, Institute of Biology, Geobotany and Botanical Gardens, Am Kirchtor 3, 06108 Halle, Germany. matthias.hoffmann@botanik.uni-halle.de 


\section{Introduction}

The interpretation of fossil terrestrial gastropod faunas constitutes a suitable tool for paleo-ecological reconstructions in the Quaternary. The prerequisite for reconstructing ecological parameters of fossil systems is knowledge about the history of the distribution and the ecological requirements of each species or fauna community (LožeK 1964, Mania 1973, AlexandRowicz 1987, FüKÖH, Krolopp \& SÜMEgi 1995, FRANK 2006).

As far as the interglacial gastropod faunas of central Europe are concerned, the equivalent recent faunas are generally quite well known. Temperate pleistocene fauna communities are characterised - like the corresponding flora - in similar ways by exotic (southern, southeast European and Pontic) components (LOŽEK 1964, Mania 1973, Mania \& Mai 2001).
For the glacial (e.g. Weichselian) associations, however, the corresponding recent equivalents in Europe are missing. According to LOŽEK (1999), studies of glacial terrestrial gastropods to date show that the analogies with the glacial ecosystems of Central Europe should not be sought in the Arctic or sub-Arctic biomes of Europe or Northern Eurasia but are to be expected, or are indeed present, in the continental regions of Central Asia. It is also significant that certain glacial index species of molluscs were initially found in the Quaternary of Central Europe and only later recently in Central Asia.

Vallonia tenuilabris (A. BRAUN 1843) was described for the first time in the loess of Wiesbaden (Germany). It is only in the past few decades that its recent occurrence in Central Asia has been recognised. This species ranges from the Central Asian highlands (Altay, Tien

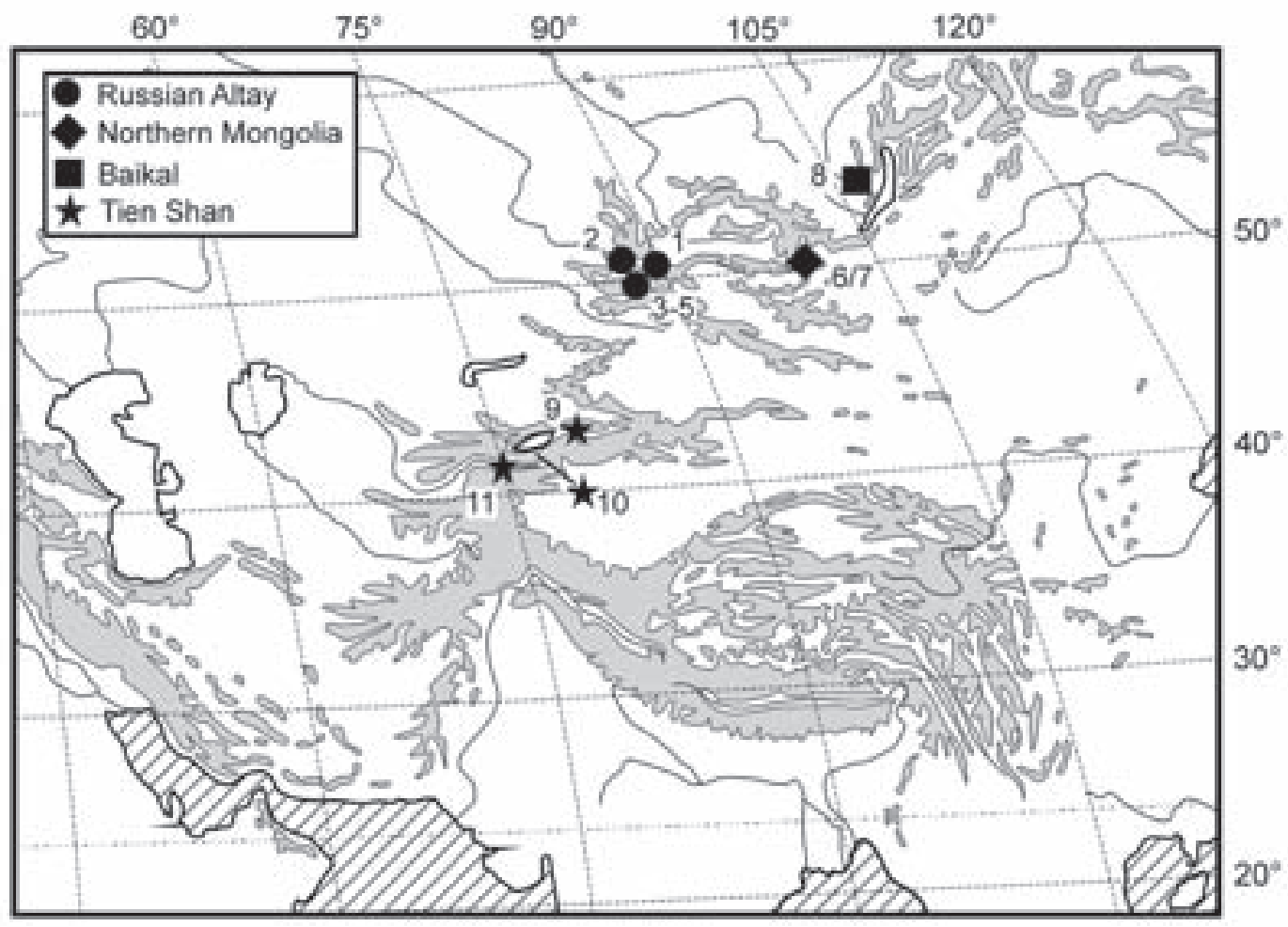

Fig. 1: Localities with Pupilla cf. loessica in Central Asia (see Table 1).

Abb. 1: Vorkommen mit Pupilla cf. loessica in Zentralasien (s. Tab. 1). 
Shan, Pamir and Himalayas), Northern Mongolia and the Baikal region into Northern Asia (Schileyko 1984, Uvalieva 1990, Meng 1995, GERBER 1996).

Vertigo pseudosubstriata LožEK 1954 was first identified in the Weichselian loess of Dolni Věstonice (Moravia, Czech Republic). Further Pleistocene evidence followed in Central Europe (Krolopp 1958, Meng 1995, Bibus et al. 1996). The first indications of recent occurrences of the species in the Tien Shan were submitted by MATĚKIN (LožEK 1964). UvALIEVA (1967) discovered the species anew in the Southern Altay and initially described it as Vertigo laevis (synonym). In recent times to date, this species has been found in the Tien Shan, Altay, Pamir and Himalayas where it is relatively widespread in their alpine altitudes (Schileyko 1984, Uvalieva 1990, Meng 1995). Vertigo parcedentata (A. BRAUN 1847), like Vallonia tenuilabris, was first described in the loess of Wiesbaden (BRAUN 1847). Until recently, this species was believed to be extinct. Quite surprisingly, it was found alive in the Dovrefjell, Norway (Pokryszko 1993). MEnG (2008 a) found evidence of the occurrence of $V$. parcedentata in the Altay and Tien Shan. The material has been photographed for the first time and compared with fossil material from Central Germany. Pokryszko \& HorcÁk (2007) also found evidence of the recent occurrence of this species in the Altay region. Preece, White \& Shchetnikov (2007) additionally have the first Holocene findings from the Baikal region. Parallels on this issue have also been provided by Pisidium stewarti Preston 1909. This mussel, which is known in Europe as a decidedly Pleistocene glacial species, has also been identified as recent in the Central Asian high mountainous massifs of Tien Shan, Pamir and the Himalaya (KuIPER 1962, LožEK 1964, MENG 1995, Kantor \& Sysoev 2005, Bössneck \& MeNG 2006).

In the Central Asian highlands and also in the high regions of Northern Mongolia or in the Baikal area, numerous paleoarctic, holarctic and "Scandinavian alpine" species are widespread which had become known as typical examples of the Pleistocene glacial associations of the Central European region, such as Pupilla fauna of many types and shapes, Cochlicopa lubrica (O. F. Müller 1774), Columella columella (MARTENs 1830), Vertigo genesii (GREDLER 1856), Euconulus cf. fulvus (O. F. Müller 1774), Nesovitrea petronella (L. Pfeiffer 1853), Nesovitrea hammonis (STRÖM 1765) and others (Schileyko 1984, Uvalieva 1990, Moisseeva 1996, Meng 2008a).

The glacial fauna of the Central European region also differs considerably from the present day sub-arctic or alpine gastropod associations by the characteristic occurrence of a series of species in steppe. These also include the xerothermic genus Pupilla triplicata (STUDER 1820) which is also found in the high mountainous habitats of Central Asia (SCHILEYKo 1984, LožEK 1999, Meng 2008b).

Pupilla loessica was first described by LožEK (1954) from late Pleistocene loess from Předmosti near Přerov (Moravia, Czech Republic). At an early date (1986), LožEK supported the view that Pupilla loessica was alive at the present time in Central Asia. However, no further concrete investigations of this were conducted.

The shells of Pupilla loessica are about $3 \mathrm{~mm}$ high, thin, cylindrical-ovate and have a rounded conical apex. The approximately 5 strongly curved whorls gradually increase in height and are finely and irregularly ribbed. The short elliptical aperture has no denticles, no palatal callus and is only slightly broadened. The crest is at most indicated by a weak band. The species differs from Pupilla muscorum (LinNAEus 1758) by its smaller size, the strongly rounded and ribbed whorls and the lack of denticles and crest (Fig. 3-7).

For the Pleistocene in Central and Eastern Europe and also in parts of NW Europe, Pupilla loessica constitutes a significant glacial index species (LožEK 1964, Mania 1973, AlexandROwicz 1988, 1989, MENG 1995, 1998, FüKÖH, Krolopp \& Sümegi 1995, Krolopp 2003, DmiTRUK 2004, SüMegi \& Krolopp 2006). It was widespread above all in the middle and late Pleistocene but individual specimens had also 
Table 1: Collections of Pupilla cf. loessica with accompanying fauna in Central Asia (absolute individual figures).

1. Russia, SE Altay, Khrebet Saylyugem, north east of Kosh Agach (Fig. 2.1-2), habitats (cf. Table 2), $2200-2650 \mathrm{~m}$ a.s.1., $50^{\circ} 00.30^{\prime} / 89^{\circ} 13.50^{\prime}-$ $50^{\circ} 01.45^{\prime} / 89^{\circ} 15.20^{\prime}, 08.2006$

2. Russia, Aygulakskiy Khrebet, Central Altay, north of Aktash, around Lake Sorulukol, open Pinus sibirica woodland, in low bushes and mosses, humid mesophilic, $1940 \mathrm{~m}$ a.s.1., 50³0' $/ 87^{\circ} 40^{\prime}$, 08.08.2006

3. Russia, South Central Altay, Severo Chujskiy Khrebet, south of Čibit, stony slope, in mosses, $1150 \mathrm{~m}$ a.s.1., $50^{\circ} 18^{\prime} / 87^{\circ} 30^{\prime}, 18.07 .1997$

4. Russia, South Central Altay, Severo Chujskiy Khrebet, south of Čibit, humid stream bank, 1900$2250 \mathrm{~m}$ a.s.l., $50^{\circ} 08^{\prime} / 87^{\circ} 25^{\prime}-50^{\circ} 15^{\prime} / 87^{\circ} 30^{\prime}, 07.97$

5. Russia, South East Altay, Yuzhno Chujskiy Khrebet, humid shrubland, c. $2340 \mathrm{~m}$ a.s.l., 49 $50^{\prime} / 87^{\circ} 52^{\prime}, 08.2006$

6. Northern Mongolia, western shore of Lake Khövsgöl Nuur near Khatgal, flat shore plateau in meadow with very open Larix sibirica woodland (Fig. 2.4), humid mesophilic, on pieces of wood, $1668 \mathrm{~m}$ a.s.1., 50³2'43.4”/10006'09.6”, 08.09.2001

7. Northern Mongolia, east of Khövsgöl Nuur near Khatgal, stony ground, dry slope exposed to the south (Fig. 2.3), in light soil, mesophilic, surroundings Larix sibirica woodland, $1750 \mathrm{~m}$ a.s.l., $50^{\circ} 27^{\prime} 51.99^{\prime \prime} / 100^{\circ} 14^{\prime} 35.7 ”, 09.09 .2001$

8. Russia, Yelantsy, west of the Baikal Lake, steep slope with block detritus, in moss, mesophilic, $560 \mathrm{~m}$ a.s.1., $52^{\circ} 47^{\prime} / 106^{\circ} 24^{\prime}, 10.08 .1997$

9. Kyrgyzstan, Central Tien Shan, Khrebet Sary Dzash, northern slope, alpine meadow, in part stony sub-surface, 2850-3500 $\mathrm{m}$ a.s.1., $42^{\circ} 14^{\prime} / 79^{\circ} 07^{\prime}-42^{\circ} 16^{\prime} / 79^{\circ} 08,07.1995$

10. Kyrgyzstan, Inner Tien Shan, Khrebet Terskey Alatau, northern slope, alpine meadow with abundant herbage, humid, $3400 \mathrm{~m}$ a.s.l., c. $41^{\circ} 56^{\prime} / 77^{\circ} 05^{\prime}, 01.07 .1995$

11. Kyrgyzstan, Inner Tien Shan, around Lake Song Köl, Kek Bulak valley east of the Song Köl, through flow moor, $3050 \mathrm{~m}$ a.s.1., $41^{\circ} 46^{\prime} / 75^{\circ} 23^{\prime}$, 19.07.2005

\begin{tabular}{|c|c|c|c|c|c|c|c|c|c|c|c|}
\hline & \multicolumn{5}{|c|}{ Russian Altay } & \multicolumn{2}{|c|}{ N Mong. } & \multirow{2}{*}{\begin{tabular}{|l} 
B. \\
8
\end{tabular}} & \multicolumn{3}{|c|}{ Tien Shan } \\
\hline & 1 & 2 & 3 & 4 & 5 & 6 & 7 & & 9 & 10 & 11 \\
\hline Novisuccinea altaica (MARTENS 1871) & - & 5 & - & - & - & - & - & - & 10 & - & - \\
\hline Novisuccinea cf. altaica (MARTENS 1871) & - & - & - & - & - & - & - & - & - & - & $\mathrm{X}$ \\
\hline Cochlicopa lubrica (O. F. MüLLER 1774) & - & - & 1 & - & - & - & - & - & - & - & - \\
\hline Columella columella (MARTENS 1830) & 31 & - & - & - & - & - & - & - & 31 & - & - \\
\hline Vertigo alpestris ALDER 1838 & - & 3 & - & - & - & - & - & - & 14 & - & - \\
\hline Vertigo cf. alpestris ALDER 1838 & - & - & 3 & - & - & - & - & - & - & - & - \\
\hline Vertigo genesii (GREDLER 1856) & 56 & - & - & - & - & - & - & - & - & - & $\mathrm{X}$ \\
\hline Vertigo parcedentata (A. BRAUN 1847) & - & - & - & 2 & - & - & - & - & 2 & - & - \\
\hline Pupilla alluvionica MENG \& HOFFMANN 2008 & 90 & - & - & - & - & - & - & - & - & - & - \\
\hline Pupilla cf. loessica LOžEK 1954 & 750 & 3 & 2 & 10 & 29 & 95 & 11 & 33 & 28 & 6 & $\mathbf{X}$ \\
\hline Pupilla muscorum (LINNAEUS 1758) & - & 5 & - & 26 & - & 75 & - & - & - & - & $\mathrm{X}$ \\
\hline Pupilla turcmenica (O. BOETTGER 1889) & - & - & - & - & - & - & - & - & 96 & - & - \\
\hline Vallonia kamtschatica LIKHAREV 1963 & - & - & 2 & - & - & - & 14 & 27 & - & - & - \\
\hline Vallonia cf. ladacensis (NEVILL 1878) & - & - & - & - & - & - & - & - & 18 & - & - \\
\hline Vallonia tenuilabris (A. BRAUN 1843) & 183 & - & - & 1 & - & 112 & 5 & - & 24 & 9 & - \\
\hline Vallonia sp. & - & - & - & - & - & - & - & - & - & - & $\mathrm{X}$ \\
\hline Nesovitrea petronella (L. PFEIFFER 1853) & - & 5 & - & - & - & - & - & - & - & - & - \\
\hline Deroceras cf. altaicum (SIMROTH 1886) & - & 1 & - & - & - & - & - & - & - & - & - \\
\hline Euconulus cf. fulvus (O. F. MÜLLER 1774) & 12 & 11 & - & 3 & - & - & - & 1 & 2 & - & - \\
\hline Euconulus cf. praticola (REINHARDT 1833) & - & - & - & - & - & - & - & - & - & - & $\mathrm{X}$ \\
\hline Fruticicola transbaikalia (SCHILEYKO 1978) & - & - & - & - & - & - & - & 10 & - & - & - \\
\hline Samples with Pupilla cf. loessica & 35 & 2 & 1 & 3 & 2 & 1 & 1 & 1 & 2 & 1 & 1 \\
\hline
\end{tabular}

B.: Baikal region, N Mong.: Northern Mongolia 
Tabelle 1: Aufsammlungen von Pupilla cf. loessica mit Begleit-Faunen in Zentralasien (absolute Individuenzahlen).

1. Russland, SE-Altay, Khrebet Saylyugem, nordöstlich Kosh-Agach (Abb. 2.1-2), Habitate (siehe Tabelle 2), 2200-2650 m NN, $50^{\circ} 00.30^{\circ} / 89^{\circ} 13.50^{\circ}-50^{\circ} 01.45^{\circ} / 89^{\circ} 15.20^{\circ}$, 08.2006

2. Russland, Aygulakskiy Khrebet, Zentral Altay, nördlich Aktash, Umfeld lake Sorulukol, offener Pinus sibirica-Wald, in niedrigen Sträuchern und Moosen, feucht-mesophil, $1940 \mathrm{~m} \mathrm{NN}$, $50^{\circ} 30^{\circ} / 87^{\circ} 40^{`}, 08.08 .2006$

3. Russland, S-Zentral Altay, Severo Chujskiy Khrebet, südlich bei Čibit, felsiger Hang, in Moosen, $1150 \mathrm{~m} \mathrm{NN}, 50^{\circ} 18^{`} / 87^{\circ} 30^{`}, 18.07 .1997$

4. Russland, S-Zentral-Altay, Severo Chujskiy Khrebet, südlich von Čibit, feuchte Bachufer, 1900$2250 \mathrm{~m} \mathrm{NN}, 50^{\circ} 08^{\circ} / 87^{\circ} 25^{\circ}-50^{\circ} 15^{\circ} / 87^{\circ} 30^{\circ}, 07.97$

5. Russland, SE-Altay, Yuzhno Chujskiy Khrebet, feuchte Staudenflur, ca. $2340 \mathrm{~m} \mathrm{NN}$, $49^{\circ} 50^{\circ} / 087^{\circ} 52^{\circ}, 08.2006$

6. N-Mongolei, westliche Ufer des lake KhövsgölNuur bei Khatgal, flaches Ufer-Plateau mit Wiese in offenen Larix sibirica-Beständen (Abb.

been found since the early Pleistocene (MüNZING 1968, Mania 1973). This species often accompanies the so-called Pupilla fauna and Columella fauna (according to LožEK 1964). Although it is a frequent loess mollusc (LožEK 1965), it apparently lived in various glacial habitats. In addition to Pupilla spp., species which like humidity, such as Columella columella or Vertigo genesii, are also often found together with Pupilla loessica.

Indications of the occurrence of Pupilla loessica in late Pleistocene loess have also been found in southern Siberia (LAURIN et al. 2000, VELICHKEVICH et al. 2004). However, in the loess sequences of Southern Tajikistan and Southern Kazakhstan no evidence has been found as yet of Pupilla loessica (Meng 2008 b, Meng \& Gerber 2008). The diversity of the Central Asian Pupillidae is generally relatively complex (SCHILEYKO 1984, Uvalieva 1990, Meng \& Hoffmann 2008). The following varieties have been found to date in the Altay region: Pupilla muscorum (Linnaeus 1758), Pupilla triplicata (STUder 1820), the
2.4), feucht-mesophil, an Hölzern, $1668 \mathrm{~m} \mathrm{NN}$, $50^{\circ} 32^{\prime} 43,4^{4}$ “'10006'09, 6“" 08.09.2001

7. N-Mongolei, östlich Khövsgöl-Nuur bei Khatgal, Felsflur, südlich exponierter Trockenhang (Abb. 2.3), in Mulm, mesophil, Umfeld Larix sibiricaWald, $1750 \mathrm{~m} \mathrm{NN}, 50^{\circ} 27^{\prime} 51,9^{\prime \prime} / 100^{\circ} 14^{\prime} 35,7^{\prime \prime}$, 09.09.2001

8. Russland, Yelantsy, westlich vom Baikalsee, Steilhang mit Blockschutt, in Moos, mesophil, $560 \mathrm{~m}$ $\mathrm{NN}, 52^{\circ} 47^{`} / 106^{\circ} 24^{`}, 10.08 .1997$

9. Kyrgyzstan, Zentral-Tien Shan, Khrebet Sary Dzash, nördlicher Hang, Hochgebirgswiesen, z. T. felsiger Untergrund, 2850-3500 $\mathrm{m} \mathrm{NN}$, $42^{\circ} 14^{\circ} / 79^{\circ} 07^{\circ}-42^{\circ} 16^{\circ} / 79^{\circ} 08,07.1995$

10.Kyrgyzstan, Innerer Tien Shan, Khrebet Terskej Alatau, nördlicher Hang, krautreiche Hochgebirgswiese, feucht, $3400 \mathrm{~m} \mathrm{NN}$, ca. $41^{\circ} 56^{\circ} / 77^{\circ} 05^{\circ}, 01.07 .1995$

11.Kyrgyzstan, Innerer Tien Shan, Umfeld Song Köl, Kek Bulak-Tal östlich des Song Köl, Durchströmungsmoor, $3050 \mathrm{~m} \mathrm{NN}, 41^{\circ} 46^{\circ} / 75^{\circ} 23^{\circ}$, 19.07.2005, leg. U. JUEG

endemic species Pupilla altaica Meng \& HoffMANN 2008 and Pupilla alluvionica Meng \& HOFFMANN 2008 as well as a number of other so far undescribed types of Pupilla (POKRYSZKO \& HorcÁK 2007, Meng \& Hoffmann 2008). In the Tien Shan area, for example, in addition to Pupilla muscorum and Pupilla triplicata, Pupilla turcmenica (O. Boettger 1889) has also been found as well as the local endemic species Pupilla gallae TzvetKov 1940, Pupilla inequidenta Schileyкo \& Almuhambetova 1979 and Pupilla striopolita SCHILEYKo 1984.

In addition to the types listed, at many sites in Central Asia during recent investigations between 1995-2006 evidence was found of a specimen so far undescribed in this region which is indistinguishable from Pupilla loessi$c a$ in its shell morphology.

\section{Material and Methods}

In connection with private visits and sponsored projects, it has been possible to investigate nu- 


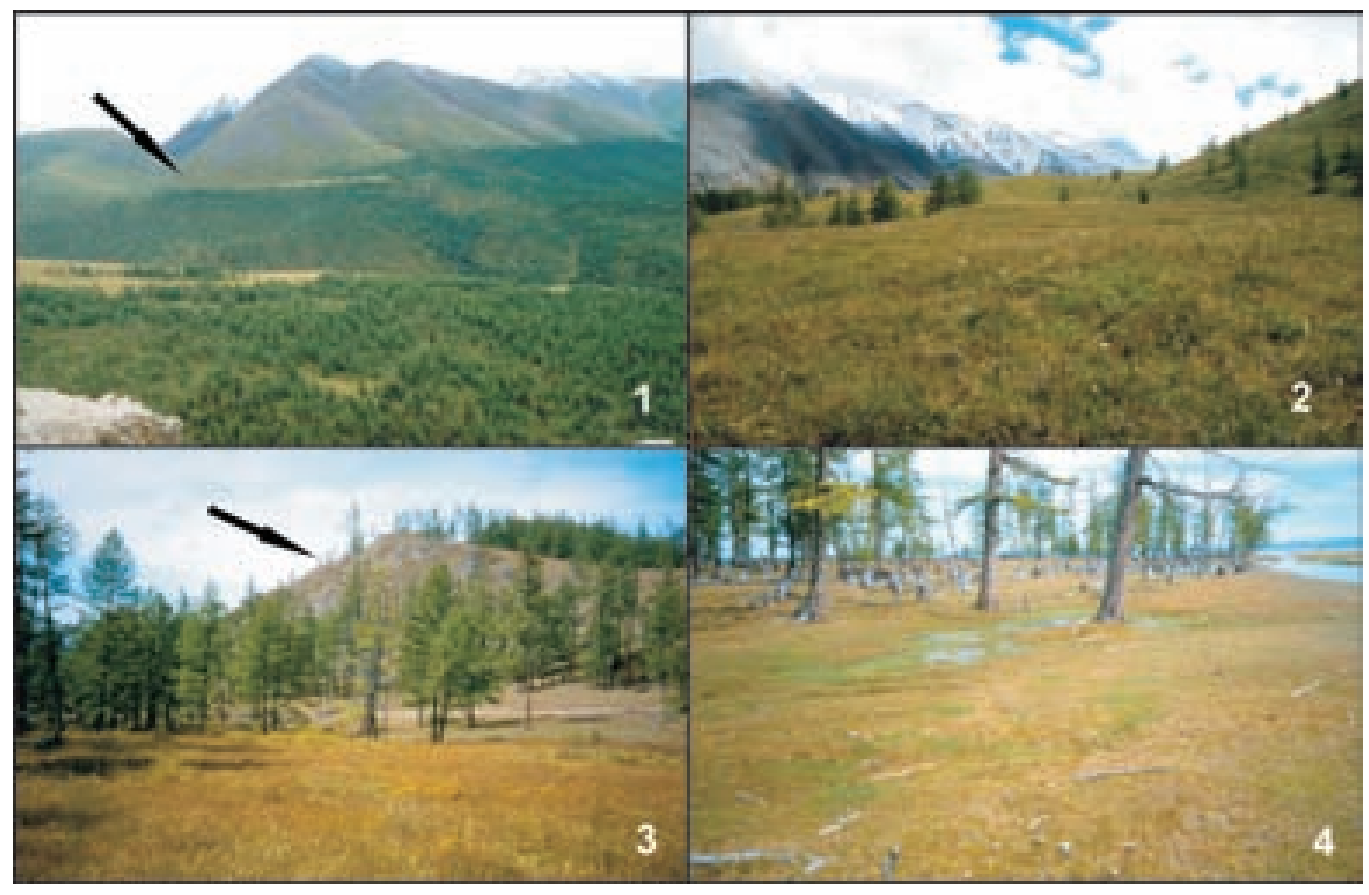

Fig. 2: Habitats of Pupilla cf. loessica in Central Asia, 1.-2. Russia, SE Altay, Khrebet Saylyugem (Table 2), 1. Panorama, 2. "Alpine tundra", $2430 \mathrm{~m}$ a.s.1. (arrow in 1. is equivalent to 2.), 3.-4. Northern Mongolia near Khatgal (Table 1/6-7), 3. East of Lake Khövsgöl Nuur, dry slope (arrow), 4. Western shore of Khövsgöl Nuur.

Abb. 2: Lebensräume von Pupilla cf. loessica in Zentralasien, 1.-2. Russland, SE-Altay, Khrebet Saylyugem (Tabelle 2), 1. Panorama, 2. „Alpine Tundra“, 2430 m NN (Pfeil in 1. entspricht 2.), 3.-4. Nord-Mongolei bei Khatgal (Tabelle 1/6-7), 3. Östlich vom See Khövsgöl Nuur, Trockenhang (Pfeil), 4. Westliche Uferbereich vom Khövsgöl Nuur.

merous recent malacocenoses in Central Asia; about 150 specimens collected in the Russian Altay (1997, 2006), 20 specimens from Northern Mongolia (2001), about 20 specimens from the Baikal region, Russia (1997) and more than 130 specimens from Tien Shan, Kyrgyzstan (1995, 1998, 1999, 2005).

The distribution and composition of the fauna communities studied including the potential $P u$ pilla loessica (Pupilla cf. loessica) were documented (Table 1-2, Fig. 1-2). The extensive section of Figures (3-7) provides a comparison between the recent material and Pleistocene forms of Pupilla loessica from Central Europa.

The fossil Pupilla loessica material from the late middle Pleistocene and late Pleistocene (Saale, Weichsel) came from various sites in
Central Germany, e.g. Erfurt (Thuringia). Freyburg and Karsdorf (Saxony-Anhalt).

\section{Results}

Altay: In the context of a single expedition supported by the DAAD in August 2006 to the Russian Altay at the intersection of the Western and Eastern Altay (Korgonskiy Khrebet, Seminskiy Khrebet, Onguday, Aykulakskiy Khrebet, Yuzhno Chujskiy Khrebet and Khrebet Saylyugem) 130 malacocenoses were examined.

Whereas only limited Pupilla cf. loessica material is available from the Central Altay, the findings were concentrated particularly in the more continental SE Altay. There were no findings from the W Altay which is maritime. Pupilla cf. loessica 


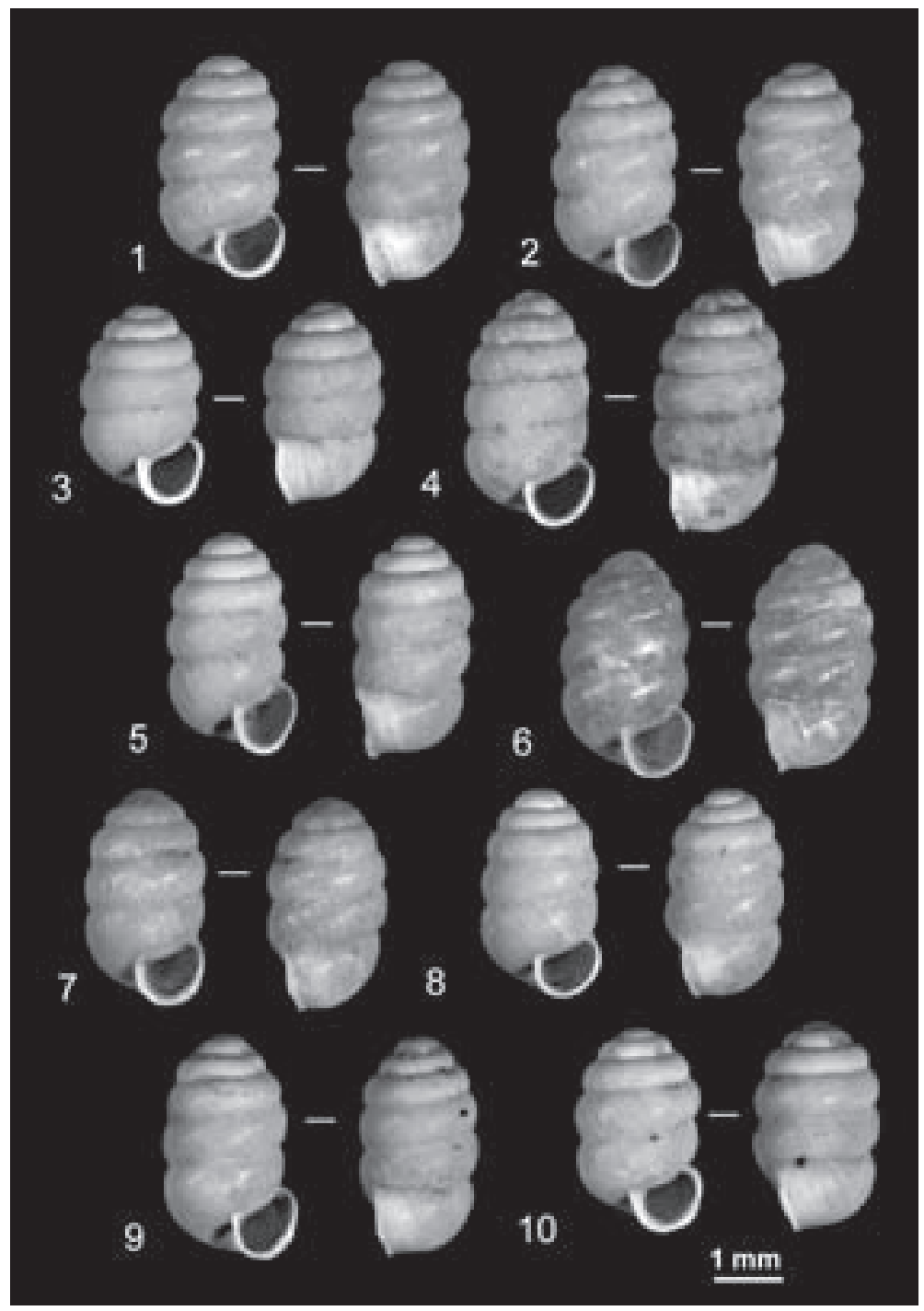

Fig. 3: Pleistocene Pupilla loessica from Central Germany.

1-2 Karsdorf/Steigra (Saxony-Anhalt), soil, Saalian Complex

3-4 Kühnhausen near Erfurt (Thuringia), late Weichsel gravel deposits of the river Gera

5 Stotternheim near Erfurt (Thuringia), early Weichsel gravel deposits of the river Gera

6 Prömmerberg near Freyburg (Saxony-Anhalt), Weichsel loess

7-8 Strienberg, Erfurt-Stedten (Thuringia), Weichsel loess

9-10 Mellingen (Thuringia), Weichsel loess

Abb. 3: Pleistozäne Pupilla loessica aus Mitteldeutschland.

1- 2 Karsdorf/Steigra (Sachsen-Anhalt), Fließerde, Saale-Komplex

3-4 Kühnhausen bei Erfurt (Thüringen), spätweichselzeitliche Flussschotter der Gera

5 Stotternheim bei Erfurt (Thüringen), frühweichselzeitliche Flussschotter der Gera

$6 \quad$ Prömmerberg bei Freyburg (Sachsen-Anhalt), weichselzeitlicher Löss

7- 8 Strienberg, Erfurt-Stedten (Thüringen), weichselzeitlicher Löss

9-10 Mellingen (Thüringen), weichselzeitlicher Löss 
Table 2: Collections of Pupilla cf. loessica in the Khrebet Saylyugem, South Eastern Altay, with accompanying fauna (absolute individual figures).

1. Alluvions, c. $2230 \mathrm{~m}$ a.s.1.

2. Mesophilic meadows some with abundant herbage, $2200-2480 \mathrm{~m}$ a.s.1.

3. Shrubland and humid stream and river banks, 2240-2400 m a.s.1.

4. Open Larix sibirica woodland, with mosses, dwarf birch and Dryas oxyodonta, 2200-2400 m a.s.l.
5. "Alpine tundra", humid alpine meadows with $D r$ yas oxyodonta and Carex sp. also showing frost cracks, 2420-2630 m a.s.l. (Fig. 2.2)

6. Dry slopes with block detritus below the tree line, snails under stones, 2250-2350 m a.s.1.

7. Dry slopes, rocky steppe type, above the tree line, snails under stones, 2410-2510 m a.s.l.

Tabelle 2: Aufsammlungen von Pupilla cf. loessica im Khrebet Saylyogem, SE Altay, mit Begleitfaunen (absolute Individuenzahlen).

1. Alluvionen, ca. $2230 \mathrm{~m} \mathrm{NN}$

2. Mesophile, z.T. kräuterreiche Wiesen, 2200$2480 \mathrm{~m} \mathrm{NN}$

3. Staudenfluren sowie feuchte Bach- und Flussufer, 2240-2400 m NN

4. Offener Larix sibirica-Wald, mit Moosen, Zwergbirke und Dryas oxyodonta, 2200-2400 m NN
5. „Hochgebirgstundra“, feuchte Hochgebirgswiesen mit Dryas oxyodonta und Carex sp. sowie Frostaufbrüche, $2420-2630 \mathrm{~m} \mathrm{NN}$ (Abb. 2.2)

6. Trockenhänge mit Blockschutt im Bereich der Waldzone, Schnecken unter Steinen, 2250$2350 \mathrm{~m} \mathrm{NN}$

7. Trockenhänge, felssteppenartig, oberhalb Waldzone, Schnecken unter Steinen, 2410-2510 m NN

\begin{tabular}{|l|c|c|c|c|c|c|c|}
\hline & $\mathbf{1}$ & $\mathbf{2}$ & $\mathbf{3}$ & $\mathbf{4}$ & $\mathbf{5}$ & $\mathbf{6}$ & $\mathbf{7}$ \\
\hline & & & & & & & \\
\hline Columella columella (MARTENS 1830) & - & - & 8 & 11 & 12 & - & - \\
\hline Vertigo genesii (GREDLER 1856) & - & - & - & 3 & 53 & - & - \\
\hline Pupilla alluvionica MENG \& HOFFMANN 2008 & 88 & - & - & - & - & 2 & - \\
\hline Pupilla cf. loessica LOžEK 1954 & $\mathbf{4}$ & $\mathbf{2 3 9}$ & $\mathbf{6 8}$ & $\mathbf{6 5}$ & $\mathbf{1 7 5}$ & $\mathbf{1 6 3}$ & $\mathbf{3 6}$ \\
\hline Vallonia tenuilabris (A. BRAUN 1843) & 5 & 33 & 46 & 3 & 64 & 32 & - \\
\hline Euconulus cf. fulvus (O. F. MÜLLER 1774) & - & - & - & 4 & 8 & - & - \\
\hline & & & & & & & \\
\hline Samples with Pupilla cf. loessica & $\mathbf{2}$ & $\mathbf{9}$ & $\mathbf{4}$ & $\mathbf{9}$ & $\mathbf{7}$ & $\mathbf{2}$ & $\mathbf{2}$ \\
\hline
\end{tabular}

occurred most frequently in the Khrebet Saylyugem (Table 1.1-5). Therefore these findings have been examined in greater detail (Table 2).

The area investigated in the Khrebet Saylyugem lies at a height of 2200-2600 m NN. The closest known meteorological station is the Kosh Agach Station (www.globalclimatics.org - Climate Diagrams, http://meteo.infospace. $\mathrm{ru}), 50^{\circ} 01^{\prime} / 88^{\circ} 44^{\prime}$ and $1750 \mathrm{~m}$ a.s.l. The average annual temperature recorded amounts to $-6.7^{\circ} \mathrm{C}$ (January $-32^{\circ} \mathrm{C}$, July $13^{\circ} \mathrm{C}$ ) and the annual rainfall amounts to about $110-150 \mathrm{~mm}$ on average. In the Khrebet Saylyugem region where we worked, however, as the height increases with corresponding exposure one can assume considerably higher rainfall.
Pupilla cf. loessica is found in various different habitats in the Khrebet Saylyugem. These habitats range from stony steppe via open woodland with Larix sibirica, shrubland, mesophilic meadows to humid high altitude meadows with Carex sp. and Dryas oxyodonta (alpine tundra). It is striking that in the Khrebet Saylyugem, despite the numerous specimens of Pupilla cf. loessica collected, the number of accompanying species identified was relatively small (Table 2). In addition, especially on the humid alpine meadows, the accompanying fauna found comprised Columella columella, Vertigo genesii, Vallonia tenuilabris and Euconulus cf. fulvus which most surprisingly correspond to those of the Pleistocene glacial habitats of 


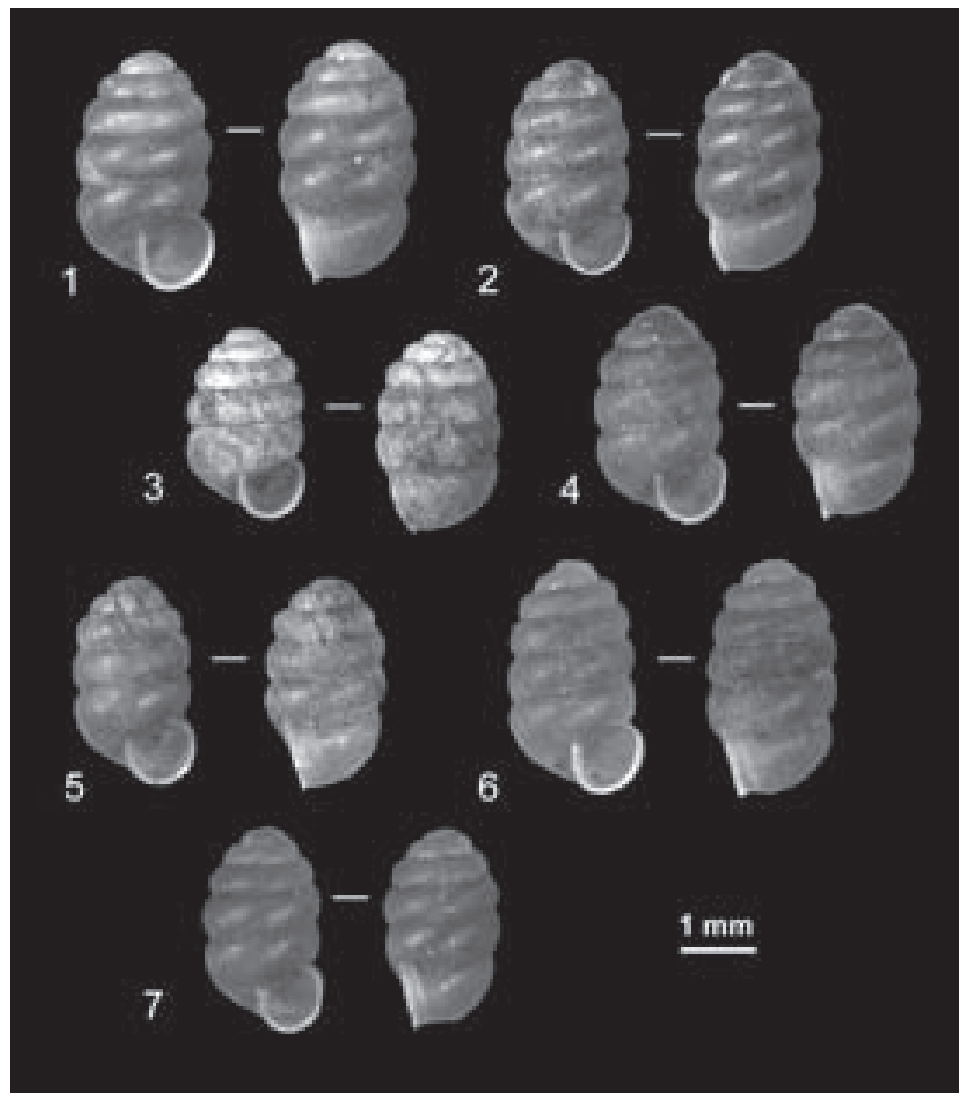

Fig. 4: Recent Pupilla cf. loessica from Russian Altay, SE Altay.

1 Yuzhno Chujskiy Khrebet, humid shrubland (Table 1/5)

2-7 Khrebet Saylyugem (Table 2, Fig. 2/1-2)

2 "Alpine tundra", humid alpin meadows

3 Mesophilic meadows

4-6 Dry slopes, rocky steppe type

7 Open Larix sibirica woodland

Abb. 4: Rezente Pupilla cf. loessica aus dem Russischen Altay, SE Altay.

1 Yuzhno Chujskiy Khrebet, feuchte Staudenflur (Tabelle 1/5)

2-7 Khrebet Saylyugem (Tabelle 2, Abb. 2/1-2)

2 "Alpine Tundra", feuchte alpine Wiesen,

3 Mesophile Wiesen,

4-6 Trockene Hänge, felssteppenartig,

7 Offener Larix sibirica Wald 


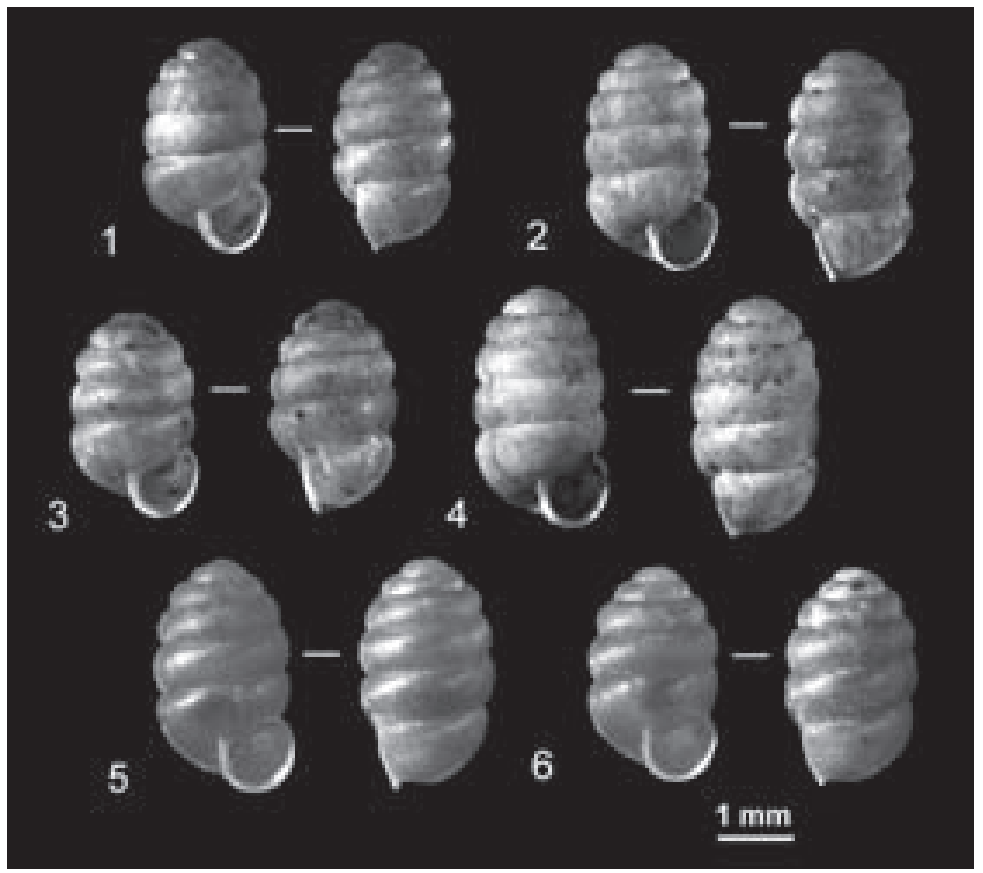

Fig. 5: Recent Pupilla $\mathrm{cf}$. loessica from Northern Mongolia and from the Baikal region.

1-3 Russia, Yelantsy, west of Baikal Lake, steep slope with block detritus (Table 1/8)

4 N Mongolia, east of Lake Khövsgöl Nuur, stony ground, dry slope (Table 1/7, Fig. 2/3)

5-6 N Mongolia, western shore of Khövsgöl Nuur, flate shore plateau (Table 1/6, Fig. 2/4)

Abb. 5: Rezente Pupilla cf. loessica aus der N-Mongolei und vom Baikal.

1- 3 Russland, Yelantsy, westlich vom Baikalsee, Trockenhang mit Gesteinsschutt (Tab. 1/8)

$4 \quad$ N-Mongolei, östlich vom See Khövsgöl Nuur, Trockenhang, felsig (Tab. 1/7, Abb. 2.3)

5- 6 N-Mongolei, westliches Ufer vom Khövsgöl Nuur, flaches Ufer-Plateau (Tab. 1/6, Abb. 2/4)

the Central European region (LožEK 1964, MANIA 1973, Meng 1995). Apart from the shell morphology criteria, the ecological conditions would also seem to indicate that the recent form found may correspond to the Pleistocene Pupilla loessica.

The cylindrical, ovate, thin-walled shells are usually a strong brown colour when fresh. The fine ribs evidence very low, fragile rims which are not always visible. On weathered shells the fine ribs are still visible although less pronounced, as on the shells of the Pleistocene $P u$ pilla loessica. The height of the shells of this recent form from the Altay amounts to c. 2.5$3.3 \mathrm{~mm}$ and the width of the shells is c. 1.6-1.8 $\mathrm{mm}$, thus also corresponding to the variations of the fossil forms (Fig. 3, 4). There were also a few larger ribbed forms and their shells were more bulbous or more cylindrical. It is not yet clear to what extent these specimens can be distinguished from Pupilla cf. loessica.

Evidence was found by the authors of Pupilla muscorum in the Altay with data so far from the Aygulakiy Khrebet and Severo Chujskiy Khrebet. However, Pupilla muscorum occurs very frequently in the Tien Shan area. This species was also found in Northern Mongolia and the Baikal region (Fig. 7).

Northern Mongolia: Two occurrences of $\mathrm{Pu}$ pilla cf. loessica were found in a mountainous region of Northern Mongolia in the area 


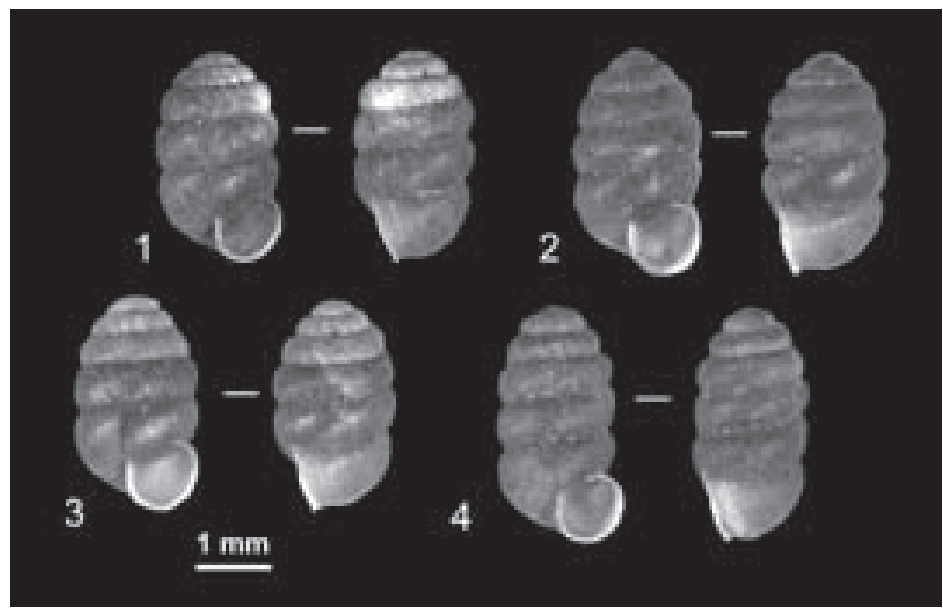

Fig. 6: Recent Pupilla $\mathrm{cf}$. loessica and Pupilla turcmenica from the Tien Shan, Kyrgyzstan

1-3 Pupilla cf. loessica (Table 1/9-11)

1 Khrebet Sary Dzash, alpine meadow

2 Khrebet Terskey Alatau, alpine meadow

3 Around Lake Song Köl, through flow moor, alpine meadow

4 Pupilla turcmenica, Khrebet Terskey Alatau, alpine meadow, $3800 \mathrm{~m}$ a.s.l.

Abb. 6: Rezente Pupilla cf. loessica und Pupilla turcmenica aus dem Tien Shan, Kyrgyzstan

1-3 Pupilla cf. loessica (Tabelle 1/9-11), 1

1 Khrebet Sary Dzash, alpine Wiesen

2 Khrebet Terskey Alatau, alpine Wiesen

3 Umfeld des Sees Song Köl, Durchströmungsmoor, alpine Wiesen

4 Pupilla turcmenica, Khrebet Terskey Alatau, alpine Wiesen, $3800 \mathrm{~m} \mathrm{NN}$

around the Khövsgöl Nuur lake near Khatgal at c. $1670 \mathrm{~m}$ a.s.1. (Table 1, 6-7). The first site was directly on the shore of the Khövsgöl Nuur on a shore plateau with a sparse scattering of Larix sibirica and mesophilic to humid meadows. Pupilla cf. loessica was accompanied by Vallonia tenuilabris and Pupilla muscorum. In neighbouring more humid shore areas Vertigo genesii and Columella columella were also found. The second site of the findings was in a stony steppe habitat and the accompanying species were Vallonia tenuilabris and Vallonia kamtschatica. Whereas the Pupilla cf. loessica from the lake shore had somewhat more ovate, bulbous shells, those from the steppe slopes were somewhat more cylindrical (Fig. 5).

The meteorological station of Khatgal (1670 m a.s.1.) in the immediate neighbourhood registered an average annual temperature of $-4.9^{\circ} \mathrm{C}$
(January $-23.2^{\circ} \mathrm{C}$, July $11.6^{\circ} \mathrm{C}$ ) and an annual rainfall of $292 \mathrm{~mm}$ which indicates the continental nature of the area. The climatic data for Northern Mongolia together with the fauna and zoo-geographical relationships also reveal interesting parallels to the conditions in the Central European glacial habitats.

Baikal Region: Specimens of Pupilla cf. loessica have also been collected from the Baikal region, Yelantsy, $560 \mathrm{~m}$ a.s.1., to the west of the Baikal lake (Table 1.8, Fig. 5). The accompanying species on the mesophilic slope with block detritus were Vallonia kamtschatica, Euconulus cf. fulvus and Fruticicola transbaikalia.

The meteorological station of Trkutsk which is relatively close $\left(52^{\circ} 16^{\prime} / 104^{\circ} 21^{\prime}\right)$, at $485 \mathrm{~m}$ a.s.l., reported average annual temperatures of 
about $0^{\circ} \mathrm{C}$ and an annual rainfall of $483 \mathrm{~mm}$. The climate can be described as sub-boreal continental.

Tien Shan: Despite the numerous findings in the Tien Shan mountains, Pupilla cf. loessica was relatively rare there (Table 1.9-11, Fig. 6). The specimens came from high altitude habitats around $3000 \mathrm{~m}$ a.s.l. or considerably higher. The habitats in the areas of the central Tien Shan where findings were made, Khrebet Sary Dzash, and in the inner Tien Shan, Khrebet Terskey Alatau, as well as the area around the Song Köl lake, are normally more humid alpine meadows, some of them with abundant herbage or with Carex sp.

The significant species adapted to the cold which were found here were again e.g. Columella columella, Vallonia tenuilabris, Vertigo genesii and Vertigo parcedentata. But, compared with the Altay region, these fauna evidenced a greater variety overall, including e.g. Novisuccinea altaica, Vertigo alpestris, Pupilla muscorum, Pupilla turcmenica, Vallonia cf. ladacensis, etc. (Meng 2008a).

The climate in the Tien Shan has a strong exposure effect as a result of radiation and more humid northern slopes. Although Central and Inner Tien Shan are generally considered arid, in the course of the differences in exposure and the variations of altitudes on the mountain slopes in the alpine region, humid conditions are sometimes found. The annual rainfall in the Khrebet Terskey Alatau can amount to as much as $900 \mathrm{~mm}$ (GotTschling 2002). In the Northern Tien Shan it can considerably exceed 1000 $\mathrm{mm}$. In the part of the Khrebet Sary Dzash studied, the annual rainfall amounts to $300-400 \mathrm{~mm}$ (Atlas Kirgizskoy SSR, 1987). The annual $0^{\circ} \mathrm{C}$ isotherm in the Northern Tien Shan is found at about $2900 \mathrm{~m}$ a.s.1. At heights in excess of 3000 $\mathrm{m}$ a.s.1., the average annual temperature is considerably below $0^{\circ} \mathrm{C}$ (Bolch 2005).

It is problematic that the Tien Shan is the main distribution area of Pupilla turcmenica because a clear differentiation of the shell morphology of this species from Pupilla cf. loessica is probably not always one hundred percent possible (Fig. 6.4). Nevertheless, the shells of Pupilla turcmen- ica are narrower and more cylindrical. The form of the aperture is also more strongly developed. The edge of the aperture is markedly thickened and a parietal denticle is also often present. The crest is more pronounced (SCHILEYKO 1984).

\section{Discussion}

Despite the opinion expressed and published by LožEK (1986) that Pupilla loessica is a recent occurrence in Central Asia, a discussion of this question has never been started. The aim of this study is to change the situation and to make some initial contributions to the discussion. The study should be understood as a basis for further investigations.

The arguments in favour of the occurrence of Pupilla loessica in Central Asia, apart from the shell morphology criteria, are the preference for more strongly continental habitats with average annual temperatures markedly below $0^{\circ} \mathrm{C}$ and the corresponding accompanying fauna adapted to the cold, e.g. Columella columella, Vertigo genesii, Vallonia tenuilabris, etc., which make these fauna clearly comparable to the Pleistocene glacial associations of the Central European region.

PoKryszKo \& HoRCÁK (2007 - World Congress of Malacology, Antwerp) mention Pupilla alabiella from the Altay (SCHILEYKo 1984). This species also shows greater morphological similarities compared with Pupilla loessica (cf. ScHILEYKO 1984). From the zoo-geographical point of view, however, there are major doubts about the occurrence of this species in the Altay because Pupilla alabiella has only been found thus far on the islands of Verchovkiy and Dva Brata in the bay of Peter the Great in the Far East, Primorskiy Kray (Schileyko 1984, Kantor \& Sysoev 2005). In addition, Pupilla cf. loessica is concentrated mainly in the strongly continental South East of the Altay and appears to be lacking in the maritime Western Altay (Table 1, 2, Fig. 1). Furthermore, the question is also unanswered why Pupilla alabiella is not more widespread in the Primorskiy Kray (Red Book, Primorskiy Kray, Gulbin \& Prozorova 2002). However, should it be established that Pupilla alabiella and Pupilla 


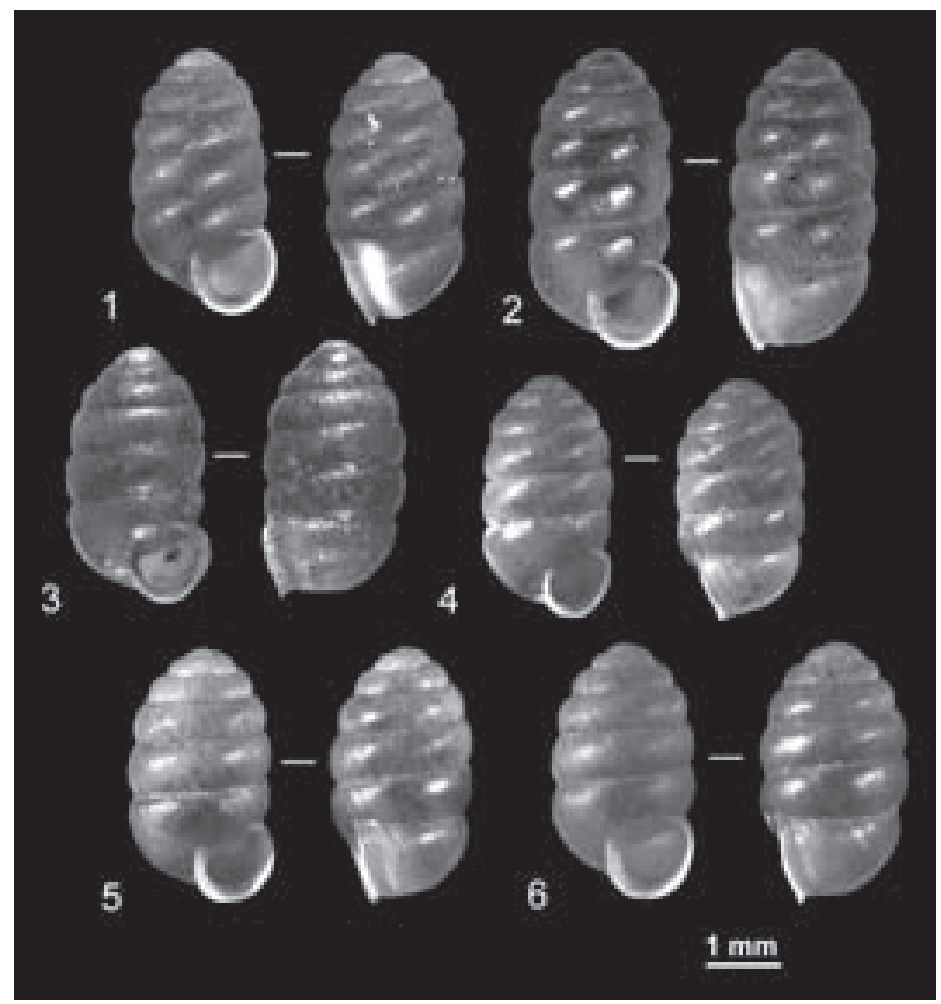

Fig. 7: Recent Pupilla muscorum in Central Asia.

1 Southern Kyrgyzstan, Tien Shan, Madygen, humid meadow, 1550 m a.s.l.

2 Kyrgyzstan, Tien Shan, Khrebet At Bai, alpine meadow, $3200 \mathrm{~m}$ a.s.l.

3 Russia, Yelantsy, west of the Baikal Lake, humid meadow, $550 \mathrm{~m}$ a.s.l.

4 Russia, South Central Altay, Severo Chujskiy Khrebet, humid meadow, 2100 m a.s.1.

5-6 N Mongolia, western shore of Khövsgöl Nuur, flate shore plateau (Table 1/6, Fig. 2/4)

Abb. 7: Rezente Pupilla muscorum in Zentralasien.

1 S.-Kyrgyzstan, Tien Shan, Madygen, feuchte Wiesen, $1550 \mathrm{~m} \mathrm{NN}$

2 Kyrgyzstan, Tien Shan, Khrebet At Bai, alpine Wiesen, 3200 m NN

3 Russland, Yelantsy, westlich vom Baikalsee, feuchte Wiesen, $550 \mathrm{~m} \mathrm{NN}$

4 Russland, S.-Zentral-Altay, Severo Chujskiy Khrebet, feuchte Wiesen, $2100 \mathrm{~m} \mathrm{NN}$

5-6 N-Mongolei, westliche Ufer vom Khövsgöl Nuur, flaches Uferplateau (Tabelle 1/6, Abb. 2/4) 
loessica are synonyms, then precedence should be given to the Pupilla loessica species according to the principle of priority.

Our study adds another piece to the puzzle of Pleistocene animal communities and their usage for climatic reconstructions. Recent analogues of the glacial environmental conditions and the species living in them may indeed be sought in the mountains of Central Asia.

\section{Acknowledgement}

The field work in Altay (2006) was supported by DAAD (German Academic Exchange Service).

\section{References}

Alexandrowicz, S.W. (1987): Analiza malakologiczna w badaniach osadów czwartorzedowych. Geologia, 13,1-2: 240 pp. (in Polish).

Alexandrowicz, S.W. (1988): Malacofauna of Late Quaternary loess-like deposits in the Polish Carpathians. - Acta Geologica Polonica, 38/1-4: 86-106.

Alexandrowicz, S.W. (1989): The Malacofauna of the younger and older loess of the Przemysl Region, SE Poland. - Folia Malacologica, 3: 7-21.

Bibus, E., Bludau, W., Bross, C. \& Rähle, W. (1996): Der Altwürm- und Rißabschnitt im Profil Mainz-Weisenau und die Eigenschaften der Mosbacher Humuszone. - Frankfurter geowissenschaftliche Arbeiten, Serie D, B 20: 21-51.

BoLCH, T. (2005): Rezenter Gletscherschwund und Klimawandel im nördlichen Tien Shan (Kasachstan/Kyrgyzstan). - Mitteilungen der Fränkischen Geographischen Gesellschaft, 52: 157-174.

Bössneck, U. \& Meng, S. (2006): Beitrag zur pleistozänen Muschelfauna Mitteldeutschlands unter besonderer Berücksichtigung der Sphaeriidae (Bivalvia: Sphaeriidae, Unionidae, Corbiculidae). - Heldia, 6/5-6: 193-204.

Braun, A. (1847): Brief vom 28. Oktober 1846. Mitteilungen an Professor Bronn gerichtet. - Neues Jahrbuch für Mineralogie, Geognosie, Geologie und Petrefakten-Kunde 1847: 49-54.

DMITRUK, P. (2004): Vernoplejstocenova fauna molljuskiv paleolitichnoi stojanki mologove $\mathrm{v}$ ta ii paleografichna interpretacija. - Visnyk Lviv University, Series Geography, 30: 104-110 (in Ukrainian).
Frank, C. (2006): Plio-pleistozäne und holozäne Mollusken Österreichs. - Mitteilungen der Prähistorischen Kommission, 62/1-2: 860 pp.

FÜKÖH, L., KROLOPP, E. \& SÜMEGI, P. (1995): Quaternary malacostratigraphy in Hungary. -Malacological Newsletter, Suppl. 1: 219 pp.

Gerber, J. (1996): Revision der Gattung Vallonia Risso 1826 (Mollusca: Gastropoda: Valloniidae). - Schriften zur Malakozoologie, 8: 227 pp.

GotTschling, H. (2002): Umweltgerechte Landnutzung im Biosphärenreservat Issyk-Kul. - 55 pp.; Heidelberg (Verlag Kasparek).

Gulbin, V.V. \& Prozorova, L.A. (2002): Molljuski - Mollusca. V Krasnuju Knigu Primorskovo Kraja (Red Book Primorskij Kraj). - 26-29 (in Russian).

Kantor, Yu. I. \& Sysoev, A. V. (2005): Catalogue of molluses of Russia and adjacent countries. 627 pp.; Moscow (KMK Scientific Press Ltd) (in Russian).

Krolopp, E. (1958): A Budai-hegység csigafaunákának kialakulása. - Állatani Közlemények: XLVL/3-4: 245-253 (in Hungarian).

Krolopp, E. (2003): Mollusc species of the Hungarian Pleistocene formations (Dec 31/2002). - Malakológiai Tájékoztató (Malacological Newsletter), 21:13-18.

Kuiper, J. G. J. (1962): Etude critique de Pisidium vincentianum. - Bulletin de l'Institut Royal des Sciences Naturelles de Belgique, 38: 1-19.

Laurin, C.A., Stasjuk, I.V., Akumova, E. B. \& ToMULova, E A. (2000): Novoe geologii pozdnepaleoliticheskovo mestonahozhdenija Debina V / Problemy archeologii, etnogtrafii, antropologii Sibiri i sopregelnych territorij. - IAE SO RAN, 6: 179-183 (in Russian).

LoŽEK, V. (1954): Neue Mollusken aus dem Tschechoslowakischen Pleistozän: Vertigo pseudosubstriata sp. n., Pupilla muscorum densegyrata ssp. n. und Pupilla loessica sp. n. - Anthropozoikum, 3: 327-343.

LožEK, V. (1964): Die Quartärmollusken der Tschechoslowakei. - Rozpravy UUG, 31: 374 pp.

LožEK, V. (1965): Das Problem der Lößbildung und der Lößmollusken. - Eiszeitalter und Gegenwart, 39: 61-75.

LožEK, V. (1986): Quaternary malacology and fauna genesis in Central Europe. - Proceedings $8^{\text {th }}$ International Malacology Congress Budapest 1983: 143-145.

LožEK, V. (1999): Kaltzeitliche Umweltbedingungen in Mitteleuropa nach Aussagen der Quartärmollusken. - In: Becker-Haumann, R. \& Frechen, 
M. (eds.): Terrestrische Quartärgeologie: 253259; Köln.

Mania, D. (1973): Paläökologie, Faunenentwicklung und Stratigraphie des Eiszeitalters im mittleren Elbe-Saalegebiet auf Grund von Molluskengesellschaften. - Geologie, 21/Beiheft 78/79: 1-175.

ManiA, D. \& MAI, D.H. (2001): Molluskenfaunen und Floren im Elbe-Saalegebiet während des mittleren Eiszeitalters. - Praehistoria Thuringica, 6/7: 46-91.

Meng, S. (1995): Die Mollusken der WeichselKaltzeit von Erfurt (Thüringen). - Veröffentlichungen des Naturkundemuseum Erfurt, 14: 150-167.

Meng, S. (1998): Mollusken (Schnecken und Muscheln) aus jungpleistozänen Geraschottern von Arnstadt-Rudisleben (Thüringen).- Veröffentlichungen des Naturhistorischen Museum Schleusingen, 13: 37-42.

Meng, S. (2008a): Neue Daten zur Verbreitung der Vertiginidae (Gastropoda: Pulmonata) in Zentralasien. - Mollusca, 26/2: 207-219.

Meng, S. (2008b): Pupilla talassika n. sp. (Gastropoda: Pulmonata: Pupillidae) from the late Pleistocene loess from West Talasskij Alatau (Southern Kazakhstan) with comments on the distribution range of Pupilla triplicate (Studer, 1820) in Central Asia. - Mollusca, 26/2: 221-228.

Meng, S. \& Gerber, J. (2008): Vallonia ranovi n. sp. from the Pleistocene of Southern Tajikistan (Gastropoda: Pulmonata: Valloniidae). - Journal of Conchology, 39/5: 599-605.

Meng, S. \& Hoffmann, M. H. (2008): Pupilla altai$c a$ n. sp. und Pupilla alluvionica n. sp., two new species of Pupillidae (Gastropoda: Pulmonata: Pupilloidea) from the Russian Altay. - Mollusca, 26/2: 229-234.

Morsseeva, S. E. (1996): Molljuski - Genetical Fund Cadastre of Kyrghyztan: 87-96 (in Russian).
MüNZING, K. (1968): Molluskenfaunen aus altpleistozänen Neckarablagerungen. - Jahrbuch des geologischen Landesamtes Baden-Württemberg, 10: 105-119.

PokryszKo, B.M. (1993): Fen malacocenoses in Dovrefjell (S. Norway). - Fauna norvegica (A), 14: 27-38.

Pokryszko, B.M. \& Horcák, M. (2007): Pupilloidea (Pupillidae, Vertiginidae, Valloniidae, Gastrocoptinae) of the Altay - a travel in space time. - World Congress of Malacology 2007: 170 (abstract).

Preece, C.R., White, D. \& Shchetnikov, A.A. (2007): Holocene molluscan successions from the lake Baikakl region, Siberia. - World Congress of Malacology 2007: 172 (abstract).

SChileyko, A.A. (1984): Nazemnye molljuski podotryda Pupillina fauny SSSR (Gastropoda, Pulmonata, Geophila). - Fauna SSSR, Molljuski, 3/3: 399 pp (in Russian).

SÜMegi, P. \& Krolopp, E. (2006): A basaharci téglagyari löszfeltárás Mollusca-faunája. -Malakológiai Tájékoztató (Malacological Newsletter), 24: 15-30 (in Hungarian).

Uvalieva, K.K. (1967): New species of land snails from South Altai. V: Molljuski i ih rol v formirovanii faun. - Trudy zoologicheskowo Instituta, XLII: 313-220 (in Russian).

Uvalieva, K. K. (1990): Land molluscs of Kazakhs$\tan$ and adjacent territories. - Academy of sciences of Kazakh SSR., Institute of Zoology: 224 pp (in Russian).

Velichkevich, F., Sanko, A., Laukhin, S. Gaigales, A., Shilova, G., Arslanov, K., Kuznetsov, V. \& Maksimov, F. (2004): Palaeobotanical and palaeomalacological characteristics of Middle Siberia Kazantsovian Interglacial according to Bedoba section data. - Geologija, 46: 17-27. 